\title{
Primates of the genus Altanius (Mammalia, Primates) from the Lower Eocene of Tsagan-Khushu, southern Mongolia
}

\author{
Evgeny N. Maschenko \& Masanura Takai
}

\begin{abstract}
Altanius is one of the oldest known euprimates discovered from the Early Eocene NaranBulak Formation, Tsagan-Khushu, southern Mongolia. In this paper, we describe three additional specimens of $A$. orlovi Dashzeveg et McKenna, 1977, and establish a new species, A. magnus sp. nov., in which $\mathrm{m} 2$ is distinctly larger than in A. orlovi. The discovery of a new species of Altanius provides further information on the evolutionary history of early primates on the Eurasian continent.
\end{abstract}

KEY WORDS: euprimates, dentition morphology, Lower Eocene, Mongolia.

Evgeny N. Maschenko [evmash@mail.ru], Borissiak Paleontological Institute, Russian Academy of Sciences, Profsoyuznaia Str. 123, Moscow 117997, Russia; Masanura Takai [takai@pri.kyoto-u.ac.jp], Primate Research Institute, Kyoto University, Inuyama 484-8506, Japan.

\section{Приматы рода Altanius (Mammalia, Primates) из нижнего эоцена Цаган-Хушу, Южная Монголия}

\author{
Е.Н. Мащенко, М. Такаи
}

\begin{abstract}
PЕЗЮМЕ. Altanius - древнейший известный эупримат Азии из нижнеэоценовой пачки Бумбан свиты Наран-Булак местонахождения Цаган-Хушу, Южная Монголия. В работе описываются три новых экземпляра A. orlovi Dashzeveg et McKenna, 1977 из Цаган-Хушу. На основании морфологических различий и пропорций $\mathrm{m} 2$, устанавливается новый вид A. magnus sp. nov., у которого $\mathrm{m} 2$ значительно крупнее, чем у A. orlovi. Данные о новом виде дают дополнительную информацию об эволюции наиболее древних приматов Евразии.
\end{abstract}

КЛЮЧЕВЫЕ СЛОВА: эоприматы, морфология зубов, нижний эоцен, Монголия.

\section{Introduction}

Primate origins are one of the most interesting and controversial topics for primatologists. Many researchers accept that primates originated in North America or Europe as early as the latest Cretaceous, because many taxa of plesiadapiforms and euprimates have been discovered in Paleocene and Early Eocene sediments in these areas (Fleagle, 1999). However, recently, increased discoveries of early primates and plesiadapiforms from the Paleocene or Early Eocene in eastern Asia have prompted further controversy. Conversely, the fossil record of Altiatlasius koulchii Sigé et al., 1990, the oldest potential euprimate from the Late Paleocene of Morocco, North Africa, suggests the possibility of an African origin of the primates (Sigé et al., 1990). Recently some new genera of primates have discovered in the Lower and Middle Eocene of Asia (Gunnell et al., 2008; Ni et al., 2010), but the oldest primates are known only from Paleocene of North America and Africa.

In this paper, we report some additional specimens of Altanius discovered in the Lower Eocene NaranBulak Formation of Tsagan-Khushu locality, southern Mongolia. This material was collected by the Joint
Soviet-Mongolian Paleontological Expedition in 19701991. In this article we compare the new specimens with the plesiadapiforms and euprimates (adapoids and omomyoids) discovered in the early Paleogene of eastern Asia.

Altanius was first discovered in the 1970s and was originally described as a member of the Omomyidae (Dashzeveg \& McKenna, 1977). However, some researchers regarded it as a plesiadapiform (Rose \& Krause, 1984) and others assigned it just to the early euprimates without familial attribution (Gingerich et al., 1991; Rose, 1995; Beard, 1998, 2006; Fleagle, 1999). Thus, the phylogenetic position of Altanius is still contentious, although most recent workers treat it as an enigmatic possible euprimate (Fleagle, 1999; Gunnell \& Rose, 2002; Rose, 2006).

The Tsagan-Khushu locality is situated in the TransAltai Gobi, which occupies the western part of the Nemegt Basin, $6 \mathrm{~km}$ west of the Naran-Bulak stream (Fig. 1). Its geographical coordinates are approximately $100^{\circ} 15^{\prime}-102^{\circ} 00^{\prime} \mathrm{E}$ and $43^{\circ} 45^{\prime} \mathrm{N}$ (Dashzeveg \& McKenna, 1977). The Tsagan-Khushu locality was first discovered by the Soviet-Mongolian Paleontological Expedition organized by the USSR Academy of Sciences. 


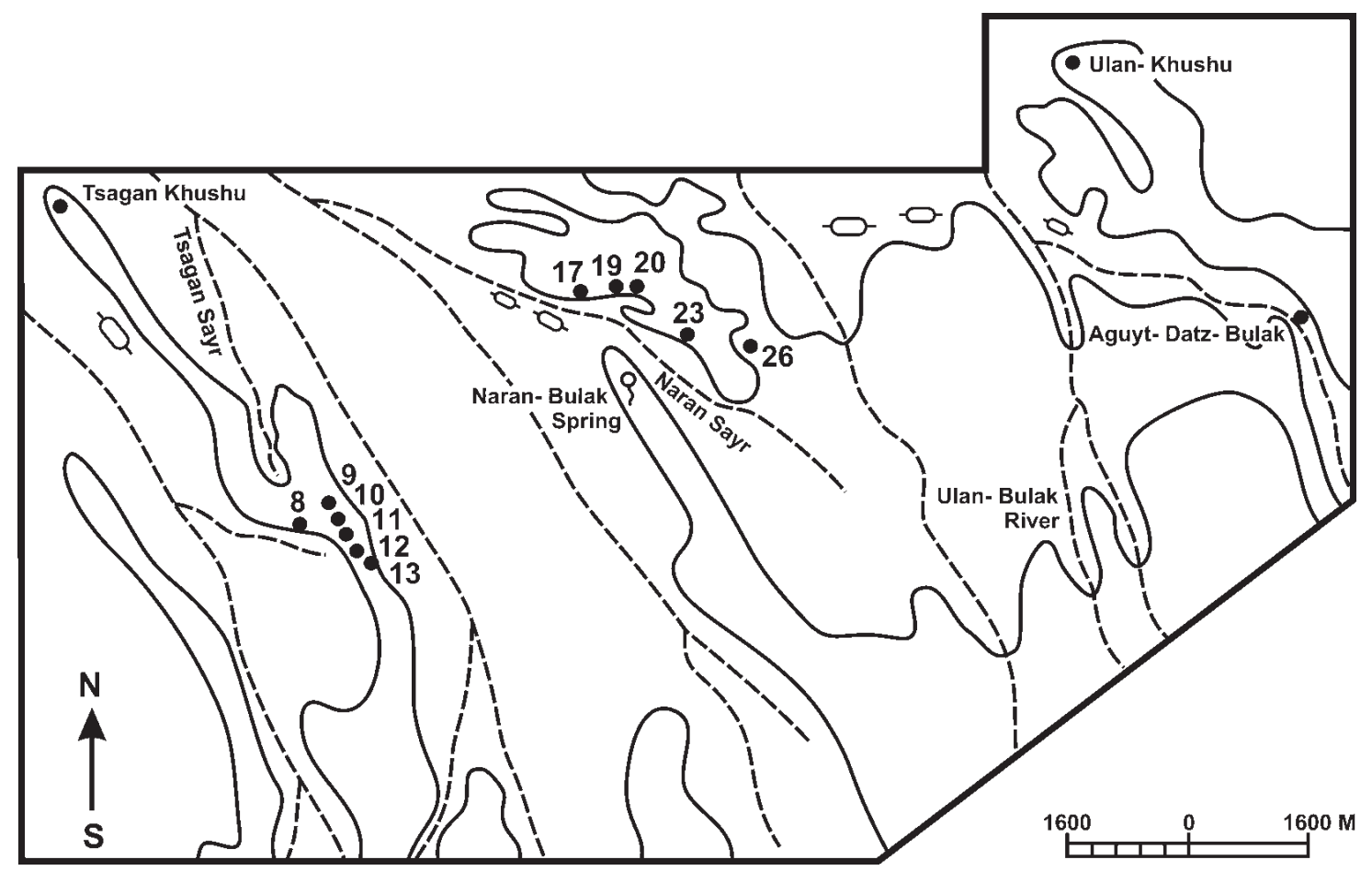

Figure 1. Detailed map of the Tsagan-Khushu locality. Filled circles with numbers represent (geological) observation and collection points. Modified from Badamgarav \& Reshetov (1985).

A complete section at the Tsagan-Khushu locality was exposed in the 1980s, along the eastern edge of the Tsagan-Sayr (Fig. 1). The section exposed the deposits of the Naran-Bulak Formation divided in Zhigden, Naran, Bumban, Aguyt, and Ulan-Khure members (Badamgarav \& Reshetov, 1985).

Dashzeveg (1982) considered the Zhigden and Naran members to be the Upper Paleocene, correlating with the Clarkforkian, and the Bumban Member to be the Lower Eocene, correlating with the Wasatchian NALMAs (North American Land Mammal Age), respectively. This dating of the Tsagan-Khushu section was followed by Badamgarav \& Reshetov (1985) and other researchers.

All the present specimens of Altanius come from the base of the Upper Red Beds, corresponding to the Lower Eocene Bumban Member of the Naran-Bulak Formation. The material was screen-washed from the outlier at the right edge of the Tsagan-Sayr coulee watercourse and from the edge itself. This site corresponds to observation points 11,12 and 13 located at the right bank wall and in the isolated rock (eastern slope) (Badamgarav \& Reshetov, 1985) (Fig. 1). The field work was conducted by the party of the SovietMongolian Paleontological Expedition headed by Valery Reshetov in 1970-1973, 1976, 1978-1980, 1985, 1987, and 1991 (Paleontological Institute USSR Academy of Sciences, Moscow). Recently the isolated rock at the right wall of Tsagan-Sayr has been completely exhaust- ed. The outlier does not exist any longer as it was completely used for screen-washing.

In the observation points where the primate specimens were discovered, the Bumban Member is represented by alternation of lacustrine clays and gravels originated in a shallow bolson-type depression. In the observation points 11 and 12 the Bumban Member is composed of variegated clays, up to $2-2.5 \mathrm{~m}$ thick, called the transitive facies by Badamgarav \& Reshetov (1985). The mammal remains from the observation points 11 and 12 were washed out of gravel lenses. In the observation point 13 , the bed yielding mammal bones is localized in the lacustrine and shallow clayey depression sediments (brick-red clays) covered by siltstones. The total thickness of this sequence does not exceed $5 \mathrm{~m}$. Small mammal remains from the site were examined by Alexey Lopatin in 2002-2003 (Lopatin, 2004, 2006).

\section{ABBREVIATIONS}

Upper dentition: I1, I2 (incisors); C (canine); P3, P4 (premolars); M1, M2, M3 (molars). Lower dentition: i1, i2 (incisors); c (canine); p3, p4 (premolars); m1, m2, m3 (molars). Abbreviations for the teeth measurements: MD - mesiodistal length, BL — buccolingual width.

PIN - Borissiak Paleontological Institute, Russian Academy of Science, Moscow, Russia; PSS - Paleontology and Stratigraphy Section of the Institute of Geology of the Mongolian Academy of Sciences, Ulan Bator, Mongolian People's Republic. 
Table 1. Dental and mandible measurements (mm) of Altanius orlovi and A. magnus sp. nov. (Dashzeveg \& McKenna, 1977; Gingerich et al., 1991).

\begin{tabular}{|c|c|c|c|c|c|c|c|c|c|c|c|}
\hline & \multicolumn{2}{|c|}{ p3 } & \multicolumn{2}{|c|}{$\mathrm{p} 4$} & \multicolumn{2}{|c|}{$\mathrm{m} 1$} & \multicolumn{2}{|c|}{$\mathrm{m} 2$} & \multicolumn{2}{|c|}{$\mathrm{m} 3$} & \multirow{2}{*}{$\begin{array}{l}\text { Mandible } \\
\text { depth at } \\
\mathrm{m} 2\end{array}$} \\
\hline & MD & $\mathrm{BL}$ & MD & $\mathrm{BL}$ & MD & $\mathrm{BL}$ & MD & $\mathrm{BL}$ & MD & $\mathrm{BL}$ & \\
\hline $\begin{array}{l}\text { A. magnus sp. nov., } \\
\text { PIN } 3104 / 1084\end{array}$ & - & - & - & - & - & - & 1.67 & 1.27 & - & - & 2.44 \\
\hline $\begin{array}{l}\text { A. orlovi, } \\
\text { PIN 3104/1083 }\end{array}$ & 0.91 & 0.59 & 1.01 & 0.82 & 1.07 & 0.94 & 1.12 & 1.13 & 1.59 & 1.05 & 2.37 \\
\hline $\begin{array}{l}\text { A. orlovi, } \\
\text { PIN No } 3104 / 1085\end{array}$ & - & - & - & - & - & - & 0.98 & 1.03 & 1.4 & 0.88 & 2.13 \\
\hline $\begin{array}{l}\text { A. orlovi, } \\
\text { PIN 3104/1086 }\end{array}$ & - & - & 1.04 & 0.84 & - & - & - & - & - & - & - \\
\hline $\begin{array}{l}\text { A. orlovi, } \\
\text { PSS } 7 / 20-8\end{array}$ & - & - & 0.93 & 0.88 & 1.09 & 1.15 & 1.08 & 1.22 & 1.58 & 1.15 & 2.40 \\
\hline $\begin{array}{l}\text { A. orlovi, } \\
\text { PSS 20-58 }\end{array}$ & 0.96 & 0.72 & 0.92 & 0.87 & 1.13 & 1.05 & 1.17 & 1.15 & 1.62 & 1.08 & 2.12 \\
\hline $\begin{array}{l}\text { A. orlovi, } \\
\text { PSS-20-85 }\end{array}$ & - & - & - & - & - & - & 1.14 & 1.05 & 1.58 & 0.92 & 2.38 \\
\hline $\begin{array}{l}\text { A. orlovi, } \\
\text { PSS 20-136 }\end{array}$ & 0.78 & 0.71 & 0.94 & 0.8 & 1.13 & 0.92 & 1.16 & 1.07 & - & - & - \\
\hline
\end{tabular}

\section{SYSTEMATIC PALEONTOLOGY}

Order Primates incertae sedis Genus Altanius Dashzeveg et McKenna, 1977 Altanius orlovi Dashzeveg et McKenna, 1977 Table 1, Fig. 2, 1-3.

Synonyms. Altanius orlovi: Dashzeveg \& McKenna, 1977, p. 127, Table 1; Gingerich et al., 1990, p. 638, Fig. 1.

Holotype: PSS 7/20-8, left mandibular fragment with $\mathrm{p} 4-\mathrm{m} 3$ ( $\mathrm{m} 2$ with damaged trigonid); southern Mongolia, Trans-Altai Gobi, Nemegt Basin, TsaganKhushu, Lower Eocene, Naran-Bulak Formation, Bumban Member.

Description. All the new material conforms to the diagnosis of the material described in previous papers, in both size and morphology (Dashzeveg \& McKenna, 1977). The unicuspid p3 has a trapezoidal occlusal outline, no paraconid, and the heel-like talonid is very small and much lower than the trigonid. The $\mathrm{p} 4$ is much higher and larger than $\mathrm{p} 3$, in both mesiodistal length and buccolingual width. The $\mathrm{p} 4$ talonid, which is much larger than that on $\mathrm{p} 3$, protrudes distolingually, retaining a small but distinct hypoconid. Although the mesiolingual part of $\mathrm{m} 1$ is somewhat damaged in the new specimen (PIN 3104/1083), $\mathrm{ml}$ is certainly smaller than $\mathrm{m} 2$ and $\mathrm{m} 3$. On the two specimens of $\mathrm{m} 2$ (PIN $3104 / 1083$ and PIN 3104/1085), the trigonid and talonid have nearly the same buccolingual width. The paraconid and metaconid are closely appressed on $\mathrm{m} 2$, whereas they are almost twinning on $\mathrm{m} 3$. The buccal cingulid is weakly developed on $\mathrm{m} 1$, whereas it is well developed at the mesiobuccal base of the trigonid on $\mathrm{m} 2$ and $\mathrm{m} 3$. The hypoconid and entoconid are approximately equal in size on $\mathrm{m} 2$, whereas the hypoconid is higher than the entoconid on $\mathrm{m} 3$. The hypoconulid is well developed, protruding distobuccally on $\mathrm{m} 3$. Both on $\mathrm{m} 2$ and $\mathrm{m} 3$, the talonid notch is relatively deep and the cristid obliqua runs mesiolingually, terminating at the distal base of the protoconid. A small hypoconulid appears on the distal margin of the talonid, situated on the central line of the tooth. There is a deep buccal groove between the hypoconid and hypoconulid.

Size. The measurements of the new specimens of $A$. orlovi are listed in Table 1.

Distribution: Lower Eocene (Bumbanian Asian Land Mammal Age), Mongolia.

Referred material: In addition to the holotype, there are the specimens PSS 20-58, dentary fragment with alveolus of i1-2, p2-3 and the p3-4 and m1-3; PSS 20-61, left maxillary fragment with the P3-M3; PSS-20-85, left mandibular fragment with damaged $\mathrm{m} 1$ and $\mathrm{m} 2-3$; PSS 20136, left dentary fragment with p3-3; PSS 20-168, left maxillary fragment with P4-3 (Gingerich et al., 1991).

New material of $A$. orlovi from the type locality includes: PIN 3104/1083, right dentary fragment preserving p3-m3 (Fig. 2, 1); PIN 3104/1085, left dentary fragment with m2-m3 (Fig. 2, 2); PIN 3104/1086, right dentary fragment with p4 (Fig. 2, 3). 

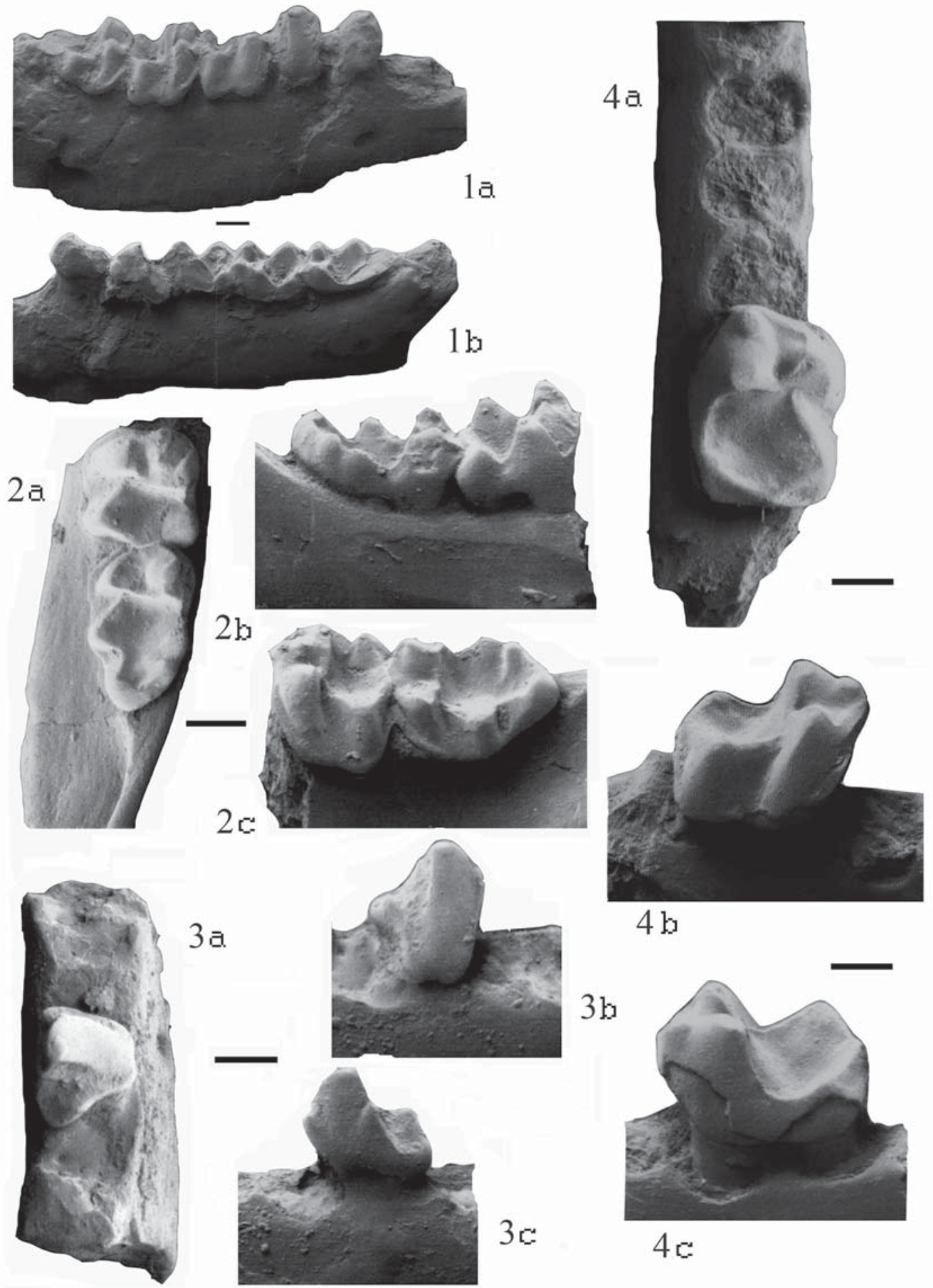

$4 \mathrm{~b}$

$3 b$

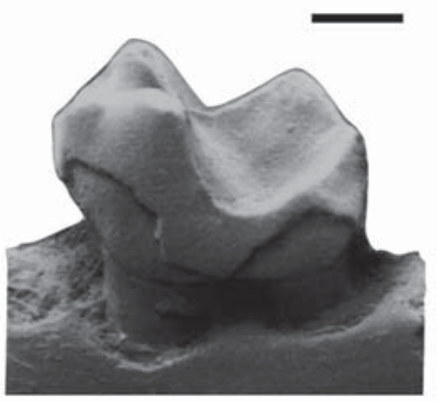

$4 c$

Figure 2. SEM micrographs and digital photo $(1 \mathrm{c})$ photos of new specimens of Altanius.

1-3. Altanius orlovi Dashzeveg et McKenna, 1977: 1 - PIN, no. 3104/1083, fragment of the right mandible with p3 - m3: 1a - buccal view, $1 b$ - lingual view; $1 c$ - occlusal view; $2-\mathrm{PIN}$, no. 3104/1085, fragment of the left mandible with $\mathrm{m} 2-\mathrm{m} 3: 2 a-$ occlusal view, $2 b$ - buccal view, $2 c$ - lingual views; 3 - PIN, no. 3104/1085, fragment of the right mandible with $\mathrm{p} 4: 3 a-$ occlusal view, $3 b-$ buccal view, $3 c$ - lingual view;

4. Altanius magnus, sp. nov., type specimen PIN 3104/1084, the fragment of the right mandible with $\mathrm{m} 2$ and alveolus of $\mathrm{p} 3-\mathrm{m} 1: 4 a-$ occlusal view, $4 b-$ buccal view, $4 c-$ lingual view; Tsagan-Khushu, Mongolia, Lower Eocene, Naran-Bulak Formation, Bumban Member. Scale bar for the figure $1 c$ is $1 \mathrm{~mm}$, scale bar for all other figures, $0.5 \mathrm{~mm}$. 


\section{Altanius magnus sp. nov.}

Fig. 2: 4.

Holotype. PIN 3104/1084, right mandibular fragment preserving $\mathrm{m} 2$ and alveoli for $\mathrm{p} 3-\mathrm{m} 1$, the only known specimen.

Etymology. Latin magnus, large. Because it is larger than $A$. orlovi, the type species.

Description of the new species. The trigonid of $\mathrm{m} 2$ is much higher than the talonid, and retains three cuspids (paraconid, metaconid, and protoconid). The metaconid and protoconid are almost the same size, but the former is slightly higher than the latter. The paraconid is conical and much smaller and lower than the others. Although the paraconid is well separated from the metaconid, there is no distinct lingual notch between the paraconid and metaconid. The paraconid is situated not centrally but more lingually, just mesial to the metaconid. The preprotocrista protrudes mesially from the protoconid and turns lingually at the mesiobuccal corner of the trigonid. There are three main cuspids on the talonid: the hypoconid, the entoconid, and an indistinct hypoconulid. The hypoconid is slightly higher than the entoconid, and the hypoconulid is located centrally, on the distal margin of the talonid. The buccal cingulid is not as well developed but a small distal cingulid is present on the buccal part of the distal face. The cristid obliqua runs mesiolingually, terminating at the distal base of the protoconid. The talonid notch is not distinct. The mandibular corpus is very shallow (about 1.5 times taller than $\mathrm{m} 2$ ) relative to $\mathrm{m} 2$ size (Tab. 1).

The specimen PIN 3104/1084 does not have a labial cingulid. It is not obliterated by wear as evidenced by the almost unworn main cuspids. In occlusal aspect, PIN 3104/1084 shows no sign of any buccolingually narrowing (Fig. 2, 4a). The molar looks wide enough.

Holotype measurements $(\mathrm{mm})$ : mandible depth at $\mathrm{m} 2-2.44, \mathrm{MD} \mathrm{m} 2-1.67, \mathrm{BL} \mathrm{m} 2-1.27$. The $\mathrm{m} 2$ height, by protoconid -1.88 .

Comparison. Lower molars are larger and proportionally longer than that of $A$. orlovi. There is no buccal cingulid on $\mathrm{m} 2$ (Fig. 2, 4). The nearly complete labial cingulid of Baataromomys and other early Eocene euprimates has been well documented (e.g., fig. 3 in Ni et al., 2007) suggesting that the labial cingulid is hard to be worn out in most fossil specimens.

Remarks. Attribution to the genus Altanius is based on the following characters: not reduced protoconid and long crown of $\mathrm{m} 2$, already mentioned in the genus diagnosis by Dashzeveg \& McKenna (1977). The new species differs from $A$. orlovi in much larger lower molar size, no distinct buccal cingulid on $\mathrm{m} 2$, and longer mesiodistal proportions in the occlusal view (Tab. 1, Fig. 2: 4). Differs from Teilhardina in having no distinct lingual trigonid notch and a less developed buccal cingulid on m2. Differs from Baataromomys Ni et al., 2007 in much smaller size and in lacking distinct buccal cingulid. Differs from Altiatlasius Sigé et al., 1990 in having a more lingually situated paraconid and a small but distinct mesiobuccal cingulid on $\mathrm{m} 2$. Dif- fers from several small Paleogene euprimates, such as Anaptomorphus Cope, 1872, Asiomomys Wang et Li, 1990, Stockia Gazin, 1958, and Utaia Gazin, 1958, in its much shallower mandibular depth. Differs from utahiin omomyines in having no enamel crenulation on the lower molar.

Material. Holotype.

Type locality and horizon. Tsagan Khushu locality, southern Mongolia, Trans-Altai Gobi, Nemegt Basin, Tsagan-Khushu, Lower Eocene, Naran-Bulak Formation, Bumban Member (Bumbanian Asian Land Mammal Age).

\section{Discussion}

The taxonomy of many euprimates and the stem groups that are still under debate is considered in a following short review of Paleocene and Eocene Asian primates.

Altanius orlovi was originally described as a member of the Anaptomorphinae Cope, 1883, Omomyidae Trouessart, 1879 , on the basis of the similarity of its lower dentition to that of the anaptomorphines (Dashzeveg \& McKenna, 1977). Several studies supported this classification (Gingerich et al., 1991; Fleagle, 1999). Some authors, however, questioned its affinity to the anaptomorphine omomyids and instead regarded it as a primitive plesiadapiform, emphasizing the similarity in the structure of $\mathrm{m} 1$ between $A$. orlovi and some carpolestid plesiadapiforms, such as Elphidotarsius Gidley, 1923 (Rose \& Krause, 1984; Rose et al., 1994; Rose, 2006). In their discussion, the rather premolariform but not blade-like $\mathrm{p} 4$ structure was considered the primitive condition of the early plesiadapiforms (Rose \& Krause, 1984).

In the 1990s, the discovery of the upper dentition of A. orlovi (Gingerich et al., 1991) and isolated teeth of Altiatlasius Sigé et al., 1990 from the latest Paleocene of Morocco (Sigé et al., 1990) allowed further progress on the knowledge of the evolution of the early primates. Many workers compared the two genera with other early primates, such as Teilhardina Simpson, 1940 and Donrussellia Szalay, 1976, and regarded both Altanius and Altiatlasius as early primates, although their phylogenetic positions were unclear because their upper dentition was mutually very different. In Altanius, M2 has a much greater buccolingual width, distinct para- and metaconules, and a discontinuous lingual cingulum, whereas in Altiatlasius, M2 is buccolingually narrow, retaining a tiny paraconule and a complete basal lingual cingulum. Based on these morphological features, most researchers consider that Altiatlasius is more derived than Altanius (Fleagle, 1999; Gunnell \& Rose, 2002) and some workers consider that Altiatlasius may even belong to the early anthropoids rather than to the omomyoid primates (Hooker et al., 1999; Beard, 2004).

Recently, there have been further progresses in the discussion of the early primates, such as Teilhardina. Ni et al. (2003) described a well-preserved skull of a 
new species of Teilhardina, T. asiatica $\mathrm{Ni}$ et al., 2003, from the earliest Eocene of China, and proposed a phylogenetic analysis of the early primates. In their conclusion, two Eurasian species of Teilhardina, $T$. belgica (Teilhard de Chardin, 1927) and T. asiatica, form a primitive independent clade, separated from another North American species, T. americana Brown, 1976. A. orlovi was included in the clade of the plesiadapiforms, rather than in that of the euprimates. However, the dental and mandibular specimens of $A$. orlovi do not show any similarity to plesiadapiforms discovered from eastern Asia.

In addition, Ni et al. (2007) described a new omomyid genus, Baataromomys Ni et al., 2007 from the Early Eocene of Inner Mongolia, China, admitting two species, B. ulaanus Ni et al., 2007 and B. brandi (Gingerich, 1993), the latter is the American species transferred from Teilhardina. They discussed the $\mathrm{m} 2$ morphology of Baataromomys in detail, comparing with many early primates including $A$. orlovi, and concluded that $A$. orlovi and Baataromomys are quite different from each other without close affinities between them. On the other hand, Baataromomys and A. magnus resemble in basic structure of $\mathrm{m} 2$, but differ from each other in much smaller size and in lacking a continuous buccal cingulid in the latter. Especially, the difference in the $\mathrm{m} 2$ size between $B$. ulaanus and A. magnus $\mathbf{s p}$. nov. is larger than the size range of Teilhardina belgica and $T$. asiatica, suggesting the taxonomic difference at least at the species level (Figure 2 of Ni et al., 2008).

Ni et al. (2010) described a new omomyid genus and species, Tarkops mckennai Ni et al., 2010 from the Early Eocene of Inner Mongolia, China. T. mckennai is not a tiny primate and is approximately more than twice as much as Altanius. But T. mckennai is substantially smaller, than Tarcadestes montanensis McKenna, 1990 from the Middle Eocene of North America. A detailed phylogenetic analysis including 59 taxa of euprimates from the Upper Paleocene and Lower Eocene of North America allowed Ni and coauthors to attribute Altanius to the omomyids. At the same time, these researchers concluded that its phylogenetic position is still unclear (Ni et al., 2010). The characters of $\mathrm{m} 2$ in Altanius differ in a reduction of buccal cingulid and in a lingually displaced paraconid.

Plesiadapiforms and euprimates have been reported from the latest Paleocene to Early Eocene sites in eastern Asia (Rose, 2006), apart from Tsagan-Khushu, such as Gashato, Wutu (Shandong Province, China), the upper part of the Lingcha Formation (Hunan Province, China), and Turpan Basin (Xinjiang Province, China). Many specimens of plesiadapiforms have been discovered, especially from Wutu, including Chronolestes simul Beard et Wang, 1995 and Carpocristes oriens Beard et Wang, 1995 (Carpolestidae) and Asioplesiadapis youngi Fu et al., 2002 (Plesiadapidae) (Beard \& Wang, 1995; Fu et al., 2002; Tong \& Wang, 2006). Altanius orlovi is quite different from Chronolestes and Carpocristes in lacking a plagiaulacoid blade on $\mathrm{p} 4$, which is the definitive feature of carpolestids (Rose, 2006). Meanwhile, A. orlovi is differentiated from Asioplesiadapis not by its $\mathrm{p} 4$ structure but by the morphology of i1, which is enormously enlarged and procumbent anteriorly in plesiadapids (Beard \& Wang, 1995; Fu et al., 2002; Tong \& Wang, 2006). According to Gingerich et al. (1991), the alveoli of the lower incisors in $A$. orlovi show that its i1 is not horizontally procumbent but inclined at an angle of about $35^{\circ}$ forward of vertical and that there is no distinct diastema between the incisors and premolars.

Recently, another carpolestid plesiadapiform, Subengius mengi Smith et al., 2004, was reported from the late Paleocene locality of Subeng in Inner Mongolia (Smith et al., 2004). The lower molars of Subengius are similar to those of $A$. orlovi, although $\mathrm{p} 4$ retains the plagiaulacoid blade, which is the typical feature of carpolestid plesiadapiforms (Smith et al., 2004; Missiaen \& Smith, 2008). Thus, A. orlovi is not similar to any member of the carpolestid or plesiadapid plesiadapiforms discovered from the early Paleogene sites of eastern Asia. The plesiadapiform affinity is thus poorly defendable for $A$. orlovi.

In Jilin Province of China, an omomyoid, Asiomomys changbaicus Beard et Wang, 1991, has been discovered from the Middle Eocene Huadian Formation (Beard \& Wang, 1991). Unlike those of A. magnus, the trigonids of $\mathrm{m} 2$ and $\mathrm{m} 3$ of Asiomomys are more mesiodistally compressed, with a centrally situated paraconid, only slightly higher than the talonid, and lingually closed by the premetacristid; the lingual talonid notch is rather strong; the hypoflexid is not deep; and the buccal cingulid is nearly complete. Thus, Asiomomy shows the typical omomyid features, suggesting a distant relationship to Altanius.

In southern Asia, several small primitive primates have also been reported from Paleogene sediments: Kohatius coppensi Russell et Gingerich, 1980 and Panobius afridi Russel et Gingerich, 1987 from the Early or early Middle Eocene of Pakistan (Russell \& Gingerich, 1980, 1987; Thewissen et al., 1997, 2001); Marcgodinotius indicus Bajpai et al., 2005, Vastanomys gracilis Bajpai et al., 2005, and Anthrasimias gujaratensis Bajpai et al., 2008 from the Early Eocene of India (Bajpai et al., 2005, 2008; Rose et al., 2006, 2009). The fossil materials of Kohatius and Panobius are isolated teeth so fragmentary that it is hard to make direct comparisons between them. Kohatius obviously differs from $A$. orlovi in having a large, conical paraconid on $\mathrm{m} 1$ and in having no paraconid and a well-developed large talonid on p4 (Russell \& Gingerich, 1981, 1987; Thewissen et al., 1997). Panobius afridi is known only from two isolated molars discovered together with Kohatius. It differs from Altanius orlovi by the large, distinct paraconid at the $\mathrm{ml}$ trigonid and by the absence of the buccal groove between the hypoconid and hypoconulid.

Marcgodinotius Bajpai et al., 2005 has been tentatively classified in the adapoids based mainly on the presence of a double-rooted $\mathrm{p} 2$ and four premolars, and 

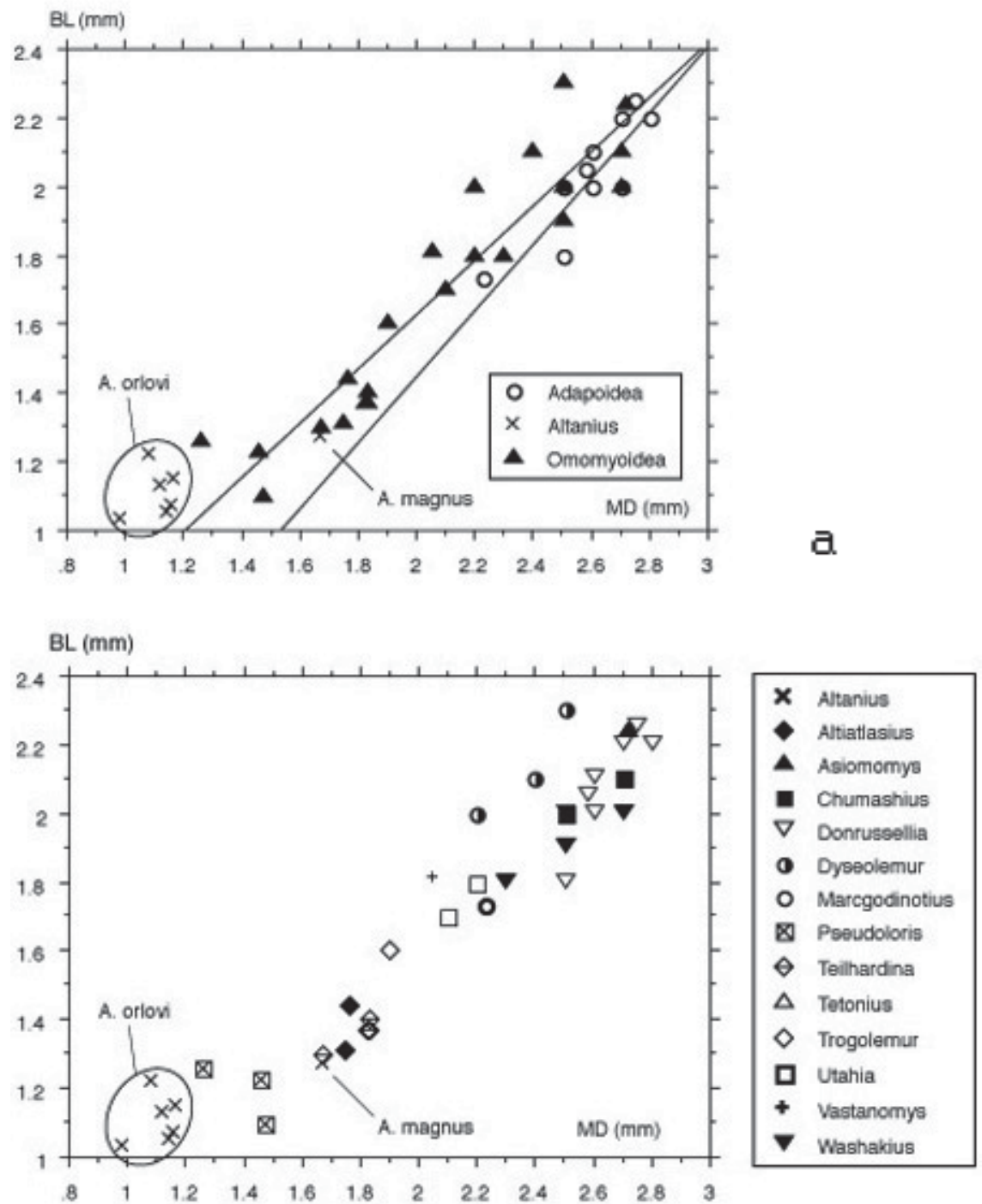

$\mathrm{b}$

Figure 3. Scatterplots of the mesiodistal length versus the buccolingual width of $\mathrm{m} 2(\mathbf{a}, \mathbf{b})$ in several tiny primitive primate taxa discussed in the text. The dental measurement data are from Gazin (1958), Russell et al. (1967), Estravis (2000), Bajpai et al. (2005), Gingerich et al. (1991), Sigé et al. (1990), Beard \& Wang (1991), Ni et al. (2003), and Szalay (1976). R² values of the regressions for the adapoids and omomyoids are 0.746 and 0.875 , respectively. Note that the measurements of Altanius orlovi fall above the regression lines of both adapoids and omomyoids. MD, mesiodistal length; BL, buccolingual width.

the relatively elongated $\mathrm{m} 3$ with a large, centrally positioned hypoconulid (Bajpai et al., 2005). Altanius orlovi is distinct from Marcgodinotius in having a double-rooted unreduced p1, a high paraconid, short talonid, and higher lingual cuspids (Bajpai et al., 2005).

Thus, A. orlovi does not show a especial resemblance to any early Paleogene euprimates or plesiadapiformes, suggesting instead an independent status. The discovery of $A$. magnus sp. nov., PIN 3104/1084, however, makes the problem more complicated. As already mentioned, $A$. magnus sp. nov. is distinctly larger than $A$. orlovi in the size of the lower molar, so it is classified as a new species of the same genus. However, the crown proportions of $\mathrm{m} 2$ are probably substantially different between the two species, indicating the possibility of a generic difference. In scatterplots of the mesiodistal length versus the buccolingual width of $\mathrm{m} 2$, $A$. orlovi is obviously located above the regression lines of the adapoids and omomyoids, whereas A. magnus sp. nov. falls on the regression lines (Fig. 3), indicating 
that $\mathrm{m} 2$ of $A$. orlovi has more mesiodistally compressed and buccolingually wide proportions than $\mathrm{m} 2$ of $A$. magnus sp. nov. and that of other tiny euprimates.

In contrast, $\mathrm{m} 2$ of $A$. magnus sp. nov. is similar to that of Marcgodinotius, Teilhardina, and Baataromomys: the paraconid is situated rather lingually and is slightly smaller and lower than the metaconid and protoconid; the hypoconulid is also centrally situated; and the small distal cingulid is present at the buccal part of the distal side. However, in Marcgodinotius, Teilhardi$n a$ and Baataromomys $\mathrm{m} 2$ retains a more complete buccal cingulid (Bajpai et al., 2005; Beard, 2006; Smith et al., 2006; Ni et al., 2007), whereas in A. magnus sp. nov.m2, of which basal enamel is unfortunately partly damaged, unlikely has continuous buccal cingulid as in these taxa. A. magnus sp. nov. may potentially be included together with Teilhardina and Baataromomys (and also with Marcgodinotius) in the same taxonomic category in the future. More specimens of lower and upper dentition of A. magnus would resolve this problem.

Apart from the taxonomic revision of these early 'primates' from eastern Eurasia (Altanius, Teilhardina, Baataromomys, Marcgodinotius, Vastanomys) and northern Africa (Altiatlasius) made possible by these materials, it is remarkable that these early 'primates' from the broad areas show similar configurations, at least in their $\mathrm{m} 2$ morphology. This similarity in $\mathrm{m} 2$ figuration among these taxa may be the primitive condition among the early euprimates, including adapoids, omomyoids, and eosimiids, in the Late Paleocene to Early Eocene. However, some workers consider such m2 morphology as the morphotype of anthropoid ancestor (Kay \& Williams, 1994), but others are suspending the judgement on the evolutionary polarity on the dental characters of $\mathrm{m} 2$ (Beard, 2006; Ni et al., 2007). If the morphological similarity in $\mathrm{m} 2$ among $A$. magnus and these Eurasian and African early primates actually correlates with a phyletic proximity, it probably means that the early euprimates were much more widely distributed in Eurasia and Africa as early as in the Late Paleocene than was previously thought.

ACKNOWLEDGEMENTS. The authors are grateful to Dr. Alexey V. Lopatin for his preliminary work with the materials from Tsagan-Khushu, Dr. Valery Y. Reshetov, the leader of the Soviet/Russian Paleontological Expedition Team, and all those who participated in the fieldwork in Mongolia. We are grateful to Dr. Ni Xijun of Institute of Vertebrate Paleontology and Paleoanthropology, China, Dr. Gregg Gunnell of the University of Michigan, USA, and Dr. Marc Godinot of Museum National d'Histoire Naturelle, Paris, France, for kindly providing us with casts of Altanius and the early primates. This research was financially supported by the Russian Foundation for Basic Research and the Japan Society for the Promotion of Science under the Russia-Japan Research Cooperative Project (ENM, grant 0604 91469; MT, grant 840064200002), and by the Global COE Program A06 of Kyoto University, Japan.

Authors thank Dr. Thierry Smith for the helpful review. The critical remarks of the anonymous reviewer gave us a possibility to improve our taxonomic arguments on the new species described. We also appreciate editorial support from the journal's board.

\section{References}

Badamgarav D. \& Reshetov V.Y. 1985. [Paleontology and stratigraphy of the Paleogene of the Transaltaic Gobi] // Transactions of Joint Soviet-Mongolian Paleontological Expedition. Vol.25. P.1-102 [in Russian, with English summary].

Bajpai S., Kapur V.V., Thewissen J.G.M., Das D.P., Tiwari B.N. \& Saravanan S.R. 2005. Early Eocene primates from Vastan lignite mine, Gujarat, western India // Journal of the Paleontological Society of India. Vol.50. No.2. P.43-54.

Bajpai S., Kay R.F., Williams B.A., Das D.P., Kapur V.V. \& Tiwari N.N. 2008. The oldest Asian record of anthropoidea // Proceedings of the National Academy of Sciences USA. Vol.105. No.32. P.11093-11098.

Beard K.C. 1998. East of Eden: Asia as an important centre of taxonomic origination in mammalian evolution // Beard K.C. \& Dawson M.R. (eds.). Dawn of the Age of Mammals in Asia. Bulletin Carnegie Museum of Natural History. No.34. P.5-39.

Beard K.C. 2004. The Hunt for the Dawn Monkey. Berkeley: University of California Press. 139 p.

Beard K.C. 2006. Mammalian biogeography and anthropoid origins // Lehman S.M. \& Fleagle J.G. (eds.). Primate Biogeography. New York: Springer. P.439-467.

Beard K.C. 2008. The oldest North American primate and mammalian biogeography during the Paleocene-Eocene Thermal Maximum // Proceedings of the National Academy of Sciences USA. Vol.105. No.10. P.3815-3818.

Beard K.C. \& Wang J. 1995. The first Asian plesiadapoids (Mammalia: Primatomorpha) // Annals of Carnegie Museum. Vol.64. Issue 1. P.1-33.

Beard K.C. \& Wang B. 1991. Phylogenetic and biogeographic significance of the tarsiiform primate Asiomomys changbaicus from the Eocene of Jilin Province, People's Republic of China // American Journal of Physical Anthropology. Vol.85. P.159-166.

Dashzeveg D. \& McKenna M.C. 1977. Tarsioid primate from the early Tertiary of the Mongolian People's Republic // Acta Paleontologica Polonica. Vol.22. No.2. P.119-137.

Dashzeveg D. 1982. [A revision of the Prodinoceratidae of Central Asia and North America] // Paleontologicheskii Zhurnal. No.1. P.95-103 [in Russian, with English summary].

Estravis C. 2000. Nuevos mam eros del Eoceno Inferior de Silveirinha (Baixo Mondego, Portugal) // Coloquios de Paleontologia. Vol.51. P.281-311.

Fleagle J.G. 1999. Primate Adaptation and Evolution // New York: Academic Press. 268 p. 
Fu J., Wang J. \& Tong Y. 2002. The discovery of the plesiadapiformes from the early Eocene of Wutu Basin, ShanDong Province // Vertebrata PalAsiatica. Vol.40. Issue 3. P.219-227.

Gazin C.L. 1958. A review of the middle and upper Eocene primates of North America // Smithsonian Miscellaneous Collections. Vol.136. P.1-112.

Gingerich P.D. 1993. Early Eocene Teilhardina brandti: oldest omomyid primate from North America // Contributions from the Museum of Paleontology, University of Michigan Vol.28. P.321-326.

Gingerich P.D., Dashzeveg D. \& Russell D.E. 1991. Dentition and systematic relationships of Altanius orlovi (Mammalia, Primates) from the early Eocene of Mongolia // Geobios. No.24. P.637-646.

Gunnell G.F. \& Rose K.D. 2002. Tarsiformes: Evolutionary history and adaptation // Hartwig W.C. (ed). The Primate Fossil Record. Cambridge: Cambridge University Press. P.45-82.

Gunnell G., Gingerich P.D., U1-Hag M., Bloch J.I., Khan I.H. \& Clyde W.C. 2008. New Primates (Mammalia) from the early and middle Eocene of Pakistan and their paleobiogeographical implications // Contributions from the Museum Paleontology, University of Michigan. Vol.32. No.1. P.1-14.

Hooker J.J., Russell D.E. \& Phélizon A. 1999. A new family of plesiadapiformes (Mammalia) from the Old World Lower Paleogene // Palaeontology. Vol.42. Issue 3. P.377-407.

Kay R.F. \& Williams B.A. 1994. Dental evidence for anthropoid origins // Fleagle J.G. \& Kay R.F. (eds.). Anthropoid Origins. New York: Plenum Press. P.361-445.

Lopatin A.V. 2004. [The first find of Geolabididae (Soricomorpha, Mammalia) in Asia (Upper Paleocene of Mongolia)] // Paleontologicheskii Zhurnal. Vol.38. Issue 6. P.672-679.

Lopatin A.V. 2006. Early Paleogene insectivore mammals of Asia and establishment of the major groups of Insectivora // Paleontologicheskii Zhurnal. Vol.40. Suppl.3 S.205S405.

Missiaen P. \& Smith T. 2008. The Gashatan (late Paleocene) mammal fauna from Subeng, Inner Mongolia, China // Acta Palaeontologica Polonica. Vol.53. Issue 3. P.357_ 378.

Ni X., Wang Y., Hu Y. \& Li C. 2004. A euprimate skull from the early Eocene of China // Nature. Vol.427. P.65-68.

Ni X., Beard K.C., Meng J., Wang Y. \& Gebo D.L. 2007. Discovery of the first early Cenozoic euprimate (Mammalia) from Inner Mongolia // American Museum Novitates. No.3571. P.1-11.

Ni X., Meng J., Beard K.C., Gebo D.L., Wang Y. \& Li C. 2010. A new tarkadectine primate from the Eocene of Inner Mongolia, China: phylogenetic and biogeographic implications // Proceedings Royal Society B. No.277. P. 247-256.

Rose K.D. 1995. The earliest primates // Evolutionary Anthropology. Vol.3. Issue 5. P.159-173.
Rose K.D. 2006. The Beginning of the Age of Mammals. Baltimore: The Johns Hopkins University Press. 429 p.

Rose K.D., Smith T., Sana R., Sahni S.A., Singh H., Missiaen P. \& Folie A. 2006. Early Eocene (Ypresian) continental vertebrate assemblage from India, with description of a new anthracobunid (Mammalia, Tethytheria) // Journal of Vertebrate Paleontology. Vol.26. Issue 1. P.219-225.

Rose K.D., Rana R.S, Sahni A., Kumar K., Missiaen P., Singh L. \& Smith T. 2009. Early Eocene Primates from Gujarat, India // Journal of Human Evolution. Vol.56. Issue 4. P.366-404.

Rose K.D., Godinot M. \& Bown T.M. 1994. The early radiation of Euprimates and the initial diversification of Omomyidae // Fleagle J.G. \& Kay R.F. (eds). Anthropoid Origins. New York: Plenum Press. P.1-28.

Rose K.D. \& Krause D.W. 1984. Affinities of the primate Altanius from the Early Tertiary of Mongolia // Journal of Mammalogy. Vol.65. Issue 4. P.721-726.

Russell D.E. \& Gingerich P.D. 1980. Un nouveau primate omomyide dans l'Eocèn du Pakistan // Comptes Rendus de l'Academie des Sciences, Paris (D). T.291. P.621-624.

Russell D.E. \& Gingerich P.D. 1987. Nouveaux primates de l'Éocène du Pakistan // Comptes Rendus de l'Academie des Sciences, Paris (Ser. II). Vol.304. P.209-214.

Russell D.E, Louis P. \& Savage D.E. 1967. Primates of the French Early Eocene // University of California Publishing, Geological Sciences. No.73. P.1-47.

Sigé B., Jaeger J.-J., Sudre J. \& Vianey-Liaud M. 1990. Altiatlasius koulchii n. gen. et sp., an omomyid primate from the Late Paleocene of Morocco, and the origins of the euprimates // Palaeontographica, Abt. A. No.241. P.31-56.

Smith T., van Itterbeeck J. \& Missiaen P. 2004. Oldest plesiadapiform (Mammalia, Proprimates) from Asia and its palaeobiogeographical implications for faunal interchange with North America // Comptes Rendus Palevol. Vol.3. No.1. P.43-52.

Smith T., Rose K.D. \& Gingerich P.D. 2006. Rapid AsiaEurope-North America geographic dispersal of earliest Eocene primate Teilhardina during the Paleocene-Eocene thermal maximum // Proceedings of the National Academy of Sciences USA. Vol.103. P.11223-11227.

Szalay F.S. 1976. Systematics of the Omomyidae (Tarsiiformes, Primates): Taxonomy, phylogeny, and adaptation // Bulletin of the American Museum of Natural History. No.156. P.1-449.

Thewissen J.G.M., Hussain S.T. \& Arif M. 1997. New Kohatius (Omomyidae) from the Eocene of Pakistan // Journal of Human Evolution. Vol.32. P.473-477.

Thewissen J.G.M., Williams E.M. \& Hussain S.T. 2001. Eocene mammal faunas from Northern Indo-Pakistan // Journal of Vertebrate Paleontology. Vol.2. Issue 2. P.347366.

Tong Y. \& Wang J. 2006. Fossil mammals from the early Eocene Wutu Formation of Shandong Province // Palaeontologia Sinica. New Series C. Vol.28. P.1-195. 